\title{
Readiness Review of BWXT for Fabrication of AGR-5/6/7 TRISO Particles
}

Project \# (s) 23841, 29412

D. W. Marshall

M. T. Sharp

February 2016

The INL is a

U.S. Department of Energy

National Laboratory

operated by

Battelle Energy Alliance

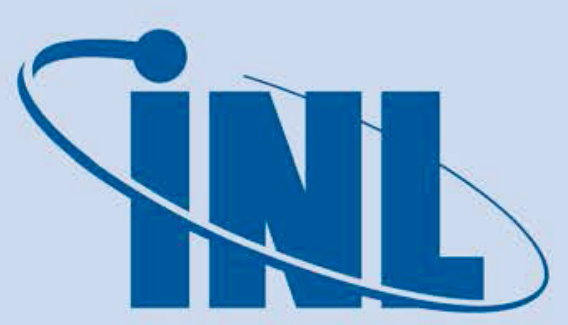

Idaho National Laboratory

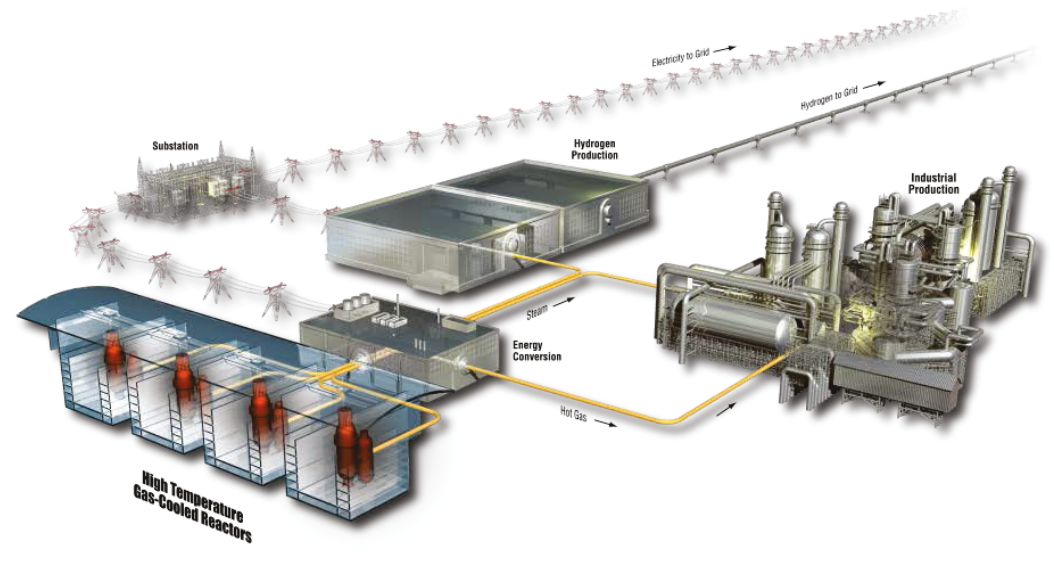




\section{DISCLAIMER}

This information was prepared as an account of work sponsored by an agency of the U.S. Government. Neither the U.S. Government nor any agency thereof, nor any of their employees, makes any warranty, expressed or implied, or assumes any legal liability or responsibility for the accuracy, completeness, or usefulness, of any information, apparatus, product, or process disclosed, or represents that its use would not infringe privately owned rights. References herein to any specific commercial product, process, or service by trade name, trade mark, manufacturer, or otherwise, does not necessarily constitute or imply its endorsement, recommendation, or favoring by the U.S. Government or any agency thereof. The views and opinions of authors expressed herein do not necessarily state or reflect

$$
\text { those of the U.S. Government or any agency thereof. }
$$


INL/EXT-16-37982

Revision 0

\section{Readiness Review of BWXT for Fabrication of AGR-5/6/7 TRISO Particles}

D. W. Marshall

M. T. Sharp

February 2016

Idaho National Laboratory

INL ART Program

Idaho Falls, Idaho 83415

http://www.inl.gov

Prepared for the

U.S. Department of Energy

Office of Nuclear Energy

Under DOE Idaho Operations Office

Contract DE-AC07-05ID14517 

INL ART Program

\section{Readiness Review of BWXT for Fabrication of AGR-5/6/7 TRISO Particles}

INL/EXT-16-37982

Revision 0

February 2016

Authors:

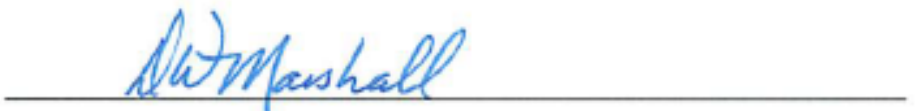

Douglas W. Marshall

Fuel Fabrication Technical Lead Engineer

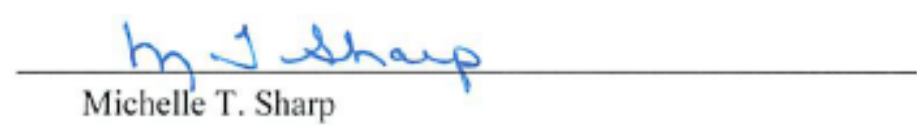

Michelle T. Sharp

INL Quality Control Services - Quality Engineer

Approved by:

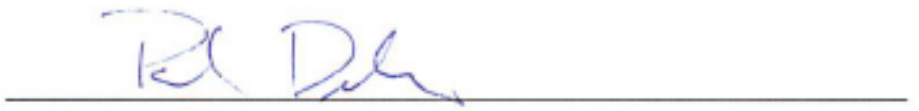

Paul A. Demkowicz

INL ART TDO AGR Fuel Lead Engineer

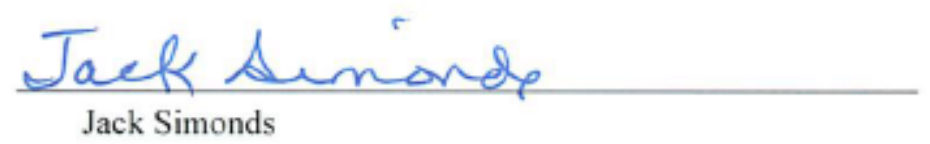

Project Manager, Fuel Development and Qualification

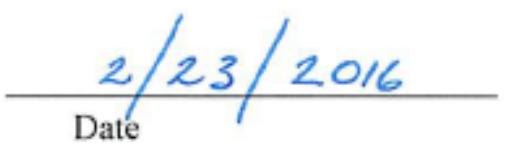

$2 / 23 / 16$

Date

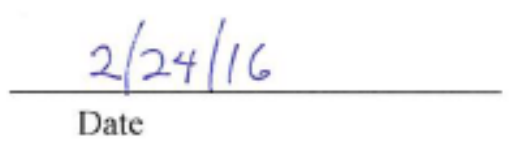

$\frac{02 / 23 / 2016}{\text { Date }}$ 


\section{SUMMARY}

Battelle Energy Alliance, LLC (BEA) conducted a readiness review at the BWX Technologies (BWXT) facility in Lynchburg, VA on February $9-10,2016$ to assess readiness to commence fabrication of tristructural isotropic (TRISO) coated fuel particles for the Advanced Gas Reactor (AGR) irradiation experiments 5, 6, and 7.

The BEA team was welcomed into the BWXT facility and given the opportunity to examine procedures, training documents, and opportunities to interview performers and management.

The review team applied NQA-1-2008/1a-2009 criteria to the following focus areas for the review:

- Process instrumentation and measurement and test equipment calibrations

- Approval, control and accessibility of operating procedures

- Process record control and accessibility

- Configuration design and control

- Operator training, certification, and qualification

- Chemical inventories for fabrication and chemical characterization

- Consumables inventories

- Material Procurements

- Operability of essential TRISO coating furnace and ancillary equipment

- Corrective actions system

- Product acceptance

- Handling and Storage

- Personnel have access to and are familiar with the latest AGR Work scope and requirements documents

With exception of three issues, BWXT is deemed to be ready to fabricate TRISO coated particles for the AGR experiments. The three issues are 1) that recent process equipment failures are still being resolved, so equipment readiness could not be verified, 2) chemical purity specifications were not fully communicated to suppliers in all cases resulting in one spare acetylene cylinder being suspect, and 3) disposition codes had not been recorded on a BWXT Quality Control Deficiency Notice to prevent possible use of the material during production coating runs.

Of these issues, the repair of the equipment is the only issue that will delay TRISO particle fabrication. The other issues are expected to be readily addressed. 


\section{ACKNOWLEDGEMENTS}

Personnel at the BWX Technologies (BWXT) facility in Lynchburg, VA were very accommodating to the review team and made a concerted effort to provide the objective evidence and requested data in advance of the readiness review. BWXT views customer reviews as a means to identify improvements that can be made in their performances. The friendly and cooperative interaction with the Idaho National Laboratory (INL) review team was appreciated. 


\section{CONTENTS}

SUMMARY viii

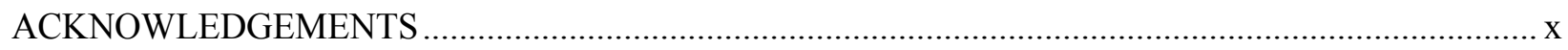

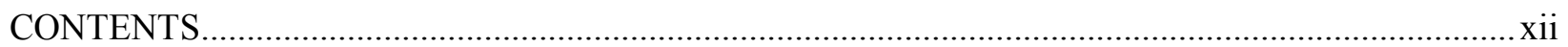

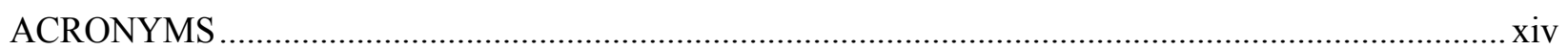

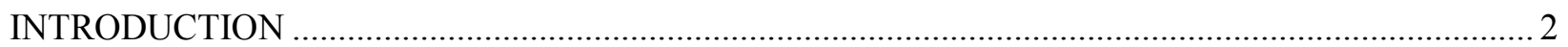

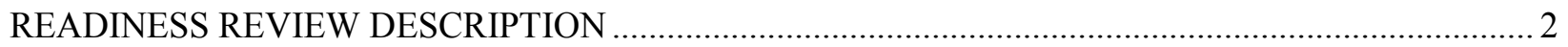

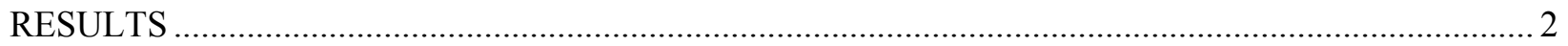

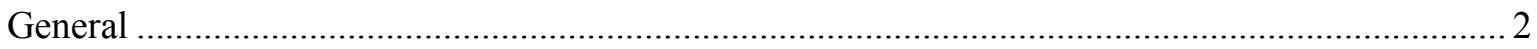

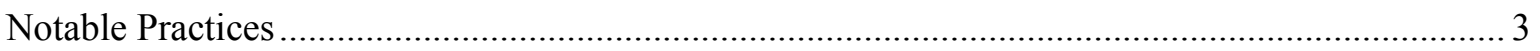

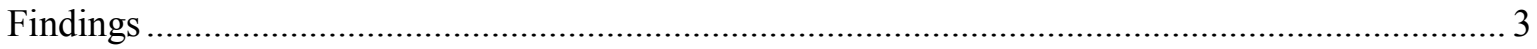

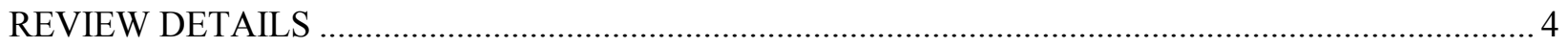

I. Process Instrumentation \& Measurement and Test Equipment Calibrations......................... 4

II. Approval, Control, and Accessibility of Operating Procedures ............................................ 4

III. Process Record Control and Accessibility .......................................................................... 5

IV. Configuration Design and Control ................................................................................. 6

V. Operator Training, Certification, and Qualification.................................................... 7

VI. Chemical Inventories for Fabrication and Chemical Characterization ................................. 7

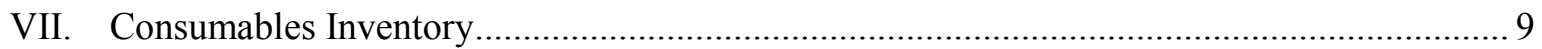

VIII. Material Procurements ............................................................................................... 9

IX. Operability of Essential TRISO Coating Furnace and Ancillary Equipment ....................... 10

X. Corrective Actions System Effectiveness to Capture "Lessons Learned" ............................. 11

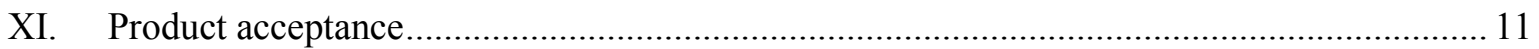

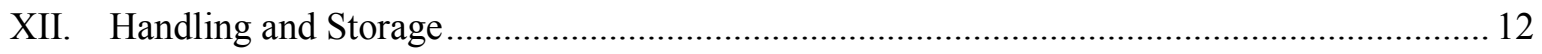

XIII. Personnel Access and Familiarity with Latest AGR Work Scope and Requirements

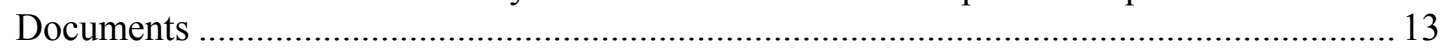

XIV. Considerations from Previous Reviews and Incidents .................................................. 13

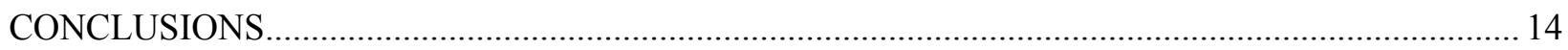

APPENDIX A CONTENTS OF THE BWXT OBJECTIVE EVIDENCE BINDER ............................A-1

APPENDIX B READINESS REVIEW ATTENDANCE SHEET …............................................. B-1

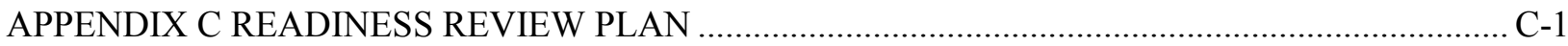




\section{ACRONYMS}

AGR Advanced Gas Reactor

ART Advanced Reactor Technology

ASME American Society of Mechanical Engineers

BEA Battelle Energy Alliance

BWXT BWX Technologies

INL Idaho National Laboratory

LEUCO low-enriched uranium carbide/oxide (kernels)

M\&TE measuring and test equipment

NQA-1 (ASME) Nuclear Quality Assurance standard

PVSS process variable specification sheet

TRISO tristructural isotropic

UCO uranium carbide/oxide 


\section{INTRODUCTION}

In support of preparations for fabricating tristructural isotropic (TRISO) coated fuel particles for the Advanced Gas Reactor fuel qualification irradiation experiments (AGR-5/6/7), Idaho National Laboratory (INL) conducted a readiness review of the BWX Technology (BWXT) company's procedures, processes, and equipment associated with TRISO coating activities.

The readiness review used quality assurance requirements taken from the American Society of Mechanical Engineers (ASME) Nuclear Quality Assurance Standard (NQA-1-2008/1a-2009) as a basis to assess readiness to start TRISO coated particle fabrication.

\section{READINESS REVIEW DESCRIPTION}

A readiness review was held at the facilities of BWX Technology Lynchburg, Virginia facility from February 9 through February 10, 2016. The purpose of the readiness review was to evaluate and determine readiness status of their TRISO particle coating processes. The readiness review was accomplished primarily through review of procedures and documents to NQA-1-2008/1a-2009 requirements. The scope of the review included:

- Process instrumentation and measurement and test equipment calibrations

- Approval, control and accessibility of operating procedures

- Process record control and accessibility

- Configuration design and control

- Operator training, certification, and qualification

- Chemical inventories for fabrication and chemical characterization

- Consumables inventories

- Material Procurements

- Operability of essential TRISO coating furnace and ancillary equipment

- Corrective actions system

- Product acceptance

- Handling and Storage

- Personnel have access to and are familiar with the latest AGR Work scope and requirements documents

\section{RESULTS}

\section{General}

BWXT was prepared for the readiness review with compiled binders of objective evidence for the reviewers and had arranged a tour of the facility and equipment. BWXT personnel were interviewed, as needed, to obtain answers to reviewer questions and to provide additional data and information. The BWXT personnel believe that readiness reviews help them strengthen their processes and helps ensure delivery of quality products to their customers. 
A recent attempted "test" run, conducted in January to verify that the coating furnace and ancillary equipment were functioning as intended, found that the desired hydrogen flow rate could not be achieved. Subsequent functional and calibration checks found that a hydrogen flow control valve had failed since the last functional check. The valve is being replaced with a calibrated spare. The existence of a failed flow control valve was self-identified by BWXT prior to the readiness review.

BWXT discovered a material deficiency in furnace while unloading the bed media from the interrupted test run. The insulation and insulators, supplied by the furnace manufacturer to protect electrical lead-ins, showed an unacceptable level of degradation. BWXT was already working with the furnace manufacturer to resolve the material deficiencies at the time of the readiness review. It is important to note that previous successful operation of the coating furnace through multiple sequential coating runs was accomplished using insulating components recently superseded by the present design and configuration, which showed degradation.

The review team cannot deem the TRISO coating furnace and ancillary equipment to be ready until multiple coating runs have been successfully completed and data collected showing that layer properties (especially density and anisotropy) are expected to meet fuel specifications during production runs.

Two findings were identified during the review (see below). These issues are not expected to delay execution of the TRISO coating runs of particles for the AGR-5/6/7 qualification fuel. BWXT corrective actions are to be documented and objective evidence submitted to INL to demonstrate readiness.

\section{Notable Practices}

NP-1. Job Order numbers are written and bar coded on cover sheets, which allows easy tracking and record retrieval.

NP-2. Storage of essential chemicals for TRISO layer density analyses are light sensitive. The BWXT analytical laboratory stores bottles of light sensitive chemicals in the original containers and over-packing sleeves inside a darkened cabinet to keep exposure to UV light as low as practical and exceeding manufacturer recommended storage practices.

NP-3. The BWXT team inspected electrical lead-in penetrations while unloading bed from an interrupted "test" run and identified significant degradation of the refractory insulation had occurred. This discovery has resulted in a much shorter delay to the program than would have occurred if the system had been operated to failure. Thanks to the BWXT team, potential causes for previous arcing events at these lead-ins have been identified and are in process of being corrected with input from the furnace manufacturer.

\section{Findings}

F-1. A review of purchase orders and certificates of analysis for acetylene showed that the minimum acetylene concentration (i.e., grade) was specified to the gas supplier, but the acceptable levels of impurities for phosphine $\left(\mathrm{PH}_{3}\right)$ and hydrogen sulfide $\left(\mathrm{H}_{2} \mathrm{~S}\right)$ were not communicated to the supplier (SPC-1363, "AGR-5/6/7 Fuel Fabrication Feedstock Chemical Pority Specifications," Rev. 2). All customer (INL) specifications applicable to a purchase must be passed down to the supplier. During the review of the certificates of analysis, it was noted that the supplier noted "Requested Purity" limits that were non-compliant with INL impurity specifications on three certificates, of which the delivered acetylene was compliant in two cases and indeterminate in a third (analysis indicated $\mathrm{PH}_{3}$ was $\leq 25 \mathrm{ppm}$ whereas the specification is for $\leq 15 \mathrm{ppm}$ ). The review team only identified one acetylene bottle that was suspect. This bottle is a reserve bottle that has not been put into service. 
F-2. A review of Quality Control Deficiency Notices (QCDNs) showed two instances of the documents signed as completed prior to the disposition codes being recorded. QCDN J52F0075 AGR Chalice diameter size and J52F-0074 - AGR Nozzle were signed without disposition codes assigned. A suggested disposition pending customer (BEA) approval was written on the forms but Form Q11-127 was signed prior to the customer's approval of this disposition on 10/31/13 (recorded on Form N-74). These instances had no negative impact due to the customer's approved disposition of "use as is". However, approval prior to assigning disposition could inadvertently allow the use of nonconforming items if the final disposition were to "reject" or "rework".

\section{REVIEW DETAILS}

\section{Process Instrumentation \& Measurement and Test Equipment Calibrations}

BWXT provided a list of calibrated instruments used in the TRISO coating process and dates when the instruments are due for recalibration. Of these, a few will expire prior to executing the AGR TRISO coated particle production runs and four were presently being recalibrated. Some of the instruments, that are readily visible from the processing floor without breaching radiological control barriers, were verified by the review team. The BWXT calibration tracking process appears to be functioning as intended and no shortcomings were identified.

\begin{tabular}{|l|l|l|}
\hline \multicolumn{2}{|l|}{ Objective Evidence } \\
\hline 1. & QWI-11.1 & Control of Measuring and Test Equipment (Calibrations) \\
\hline 2. & --- & Calibrated equipment list \\
\hline 3. & --- & Field inspection \\
\hline 4. & --- & Interviews with engineering staff and management \\
\hline
\end{tabular}

\section{Approval, Control, and Accessibility of Operating Procedures}

Managers and engineering staff review proposed changes to operating procedures and process plan outlines. Changes that could impact quality or safety are submitted to a change review board prior to issuance. Approved revisions are submitted to document control personnel who upload an electronic copy onto the SOLUMINA computer system. Only the latest revision of documents is available to plant personnel via SOLUMINA.

Instructions that are not incorporated into procedures, such as the "recipe" sheets, are prepared, independently reviewed, and signed by engineering staff. These are uploaded onto SOLUMINA on a Process Variable Specification Sheet (PVSS) for access by operating personnel. Operating procedures on SOLUMINA have 'check points' instructing the operating personnel to refer to the PVSS. PVSS instructions are run specific to a particular run.

The approval, control, and accessibility of operating procedures and instructions appear to be effective and no shortcomings were identified. It is reasonable to expect operations personnel to have the correct procedure and PVSS information. 


\begin{tabular}{|l|l|l|}
\hline \multicolumn{2}{|l|}{ Objective Evidence } \\
\hline 1. & QWI-5.1.1 Rev. 10 & Control of Plan List for Documents \\
\hline 2. & QWI-5.1.4 & Operating Procedures \\
\hline 3. & QWI 5.1.12 & Change Control \\
\hline 4. & OP-1015720 Rev. 33 & $\begin{array}{l}\text { Operating Procedure for: Coating in the CENTORR Furnace for Advanced } \\
\text { Gas Reactor Program (U) }\end{array}$ \\
\hline 5. & OP-1016020 Rev. 10 & $\begin{array}{l}\text { Operating Procedure for: AGR Coating Furnace Scrubber Operation and } \\
\text { Maintenance (U) }\end{array}$ \\
\hline 6. & OP-1015211 Rev. 5 & Operating Procedure for: Sieving for AGR (U) \\
\hline 7. & OP-1015306 Rev. 6 & Operating Procedure for: Tabler Operations for Advanced Gas Reactor (U) \\
\hline 8. & OP-1015213 Rev 2. & Operating Procedure for: Split Blend Operation for AGR (U) \\
\hline 9. & OP-0390001 & Operating Procedure for: Product Identification Control (U) \\
\hline 10. & PPO-0930001-011 & Process Plan Outline for: AGR Coating \\
\hline 11. & --- & Interviews with engineering staff and management \\
\hline
\end{tabular}

\section{Process Record Control and Accessibility}

QWI -16.1.2, UPRR Quality Assurance Records was reviewed and found compliant with NQA-12008/-1a-2009 requirements. Records are validated if stamped and signed by authorized personnel. QWI 16.1.2, Table 1 provides a comprehensive list of the project quality assurance records. Corrections to records are not allowed unless they are approved in the formal change system. A notable practice was identified during this review; the Job Order numbers are written on cover sheets and a matching bar code is also placed on the cover sheets, which allows easy tracking and record retrieval.

\begin{tabular}{|c|l|l|}
\hline \multicolumn{2}{|l|}{ Objective Evidence } \\
\hline 1. & QWI -16.1.2 & UPRR Quality Assurance Records \\
\hline 2. & $\begin{array}{l}\text { PAC- J52F Chg 093 } \\
\text { Job Order No } \\
000001115136\end{array}$ & $\begin{array}{l}\text { AGR Graphite Parts Inspection } \\
\text { RTR QA Record \# 11416 }\end{array}$ \\
\hline 3. & $\begin{array}{l}\text { PAC- J52F Chg 093 } \\
\text { Job Order No } \\
000001119871\end{array}$ & $\begin{array}{l}\text { AGR Graphite Parts Inspection } \\
\text { RTR QA Record \# 11709 }\end{array}$ \\
\hline 4. & NPN-QC-28 & Quality Control Data Sheet - AGR Nozzle Graphite \\
\hline 5. & SMT-5050021-001 & SOLUMINA Move Ticket: AGR Graphite Inspection \\
\hline
\end{tabular}




\section{Configuration Design and Control}

Configuration control is maintained by invoking a change review board whenever configuration changes are proposed and by communicating tolerances on fabrication drawings. Non-conforming parts were approved, via a N-74 Data Transmittal Form, for use in non-production runs. Configuration control appears to be effective for consumable parts.

\begin{tabular}{|c|c|c|}
\hline \multicolumn{3}{|c|}{ Objective Evidence } \\
\hline 1. & QWI 5.1.12 & Change Control \\
\hline 2. & CR-1044974-00 & Update Mixing Pot Drawing \\
\hline 3. & $\begin{array}{l}\text { Job Order No. } \\
000001115136\end{array}$ & AGR Graphite Parts Inspection \\
\hline 4. & $\begin{array}{l}\text { Job Order No. } \\
000001119781\end{array}$ & AGR Graphite Parts Inspection \\
\hline 5. & $\begin{array}{l}\text { Job Order No. } \\
000001133750\end{array}$ & AGR Graphite Heating Element Inspection \\
\hline 6. & $\begin{array}{l}\text { Job Order No. } \\
000001141679\end{array}$ & AGR Graphite Furnace Tube Inspection \\
\hline 7. & $\begin{array}{l}\text { Purchase Order } \\
47000349308 / 30 / 15\end{array}$ & Graphite Chalice, Nozzle, and Extension (SAP Req. 20020161) \\
\hline 8. & $\begin{array}{l}\text { Purchase Order } \\
47000349336 / 8 / 15\end{array}$ & $\begin{array}{l}\text { CENTORR Vacuum Industries Graphite and Other Parts for Work Station } \\
300 \text { (SAP Req. 20020230) }\end{array}$ \\
\hline 9. & UPRR-1002B & Drawing: INL 2010 AGR Nozzle and Chalice \\
\hline 10. & UPRR-10031 & Drawing: AGR Reactor Assembly \\
\hline 11. & UPRR-10032 & Drawing: AGR Reactor Tube \\
\hline 12. & UPRR-10033 & Drawing: Graphite Extension \\
\hline 13. & UPRR-10035 & Drawing: Reactor Tube Extension \\
\hline 14. & SMT-5050021-001 & SOLUMINA Move Ticket: AGR Graphite Inspection \\
\hline 15. & QCDN J52F-0074 & Quality Control Deficiency Notice on the AGR Nozzle dimensions \\
\hline 16. & QCDN J52F-0075 & Quality Control Deficiency Notice on the AGR Chalice dimensions \\
\hline 17. & N-74 J52F-002 & Data Transmittal Form: QCDN No. J52F-0074 and QCDN No. J52F-0075 \\
\hline 18. & --- & Interviews with engineering staff and management \\
\hline
\end{tabular}




\section{Operator Training, Certification, and Qualification}

Operators are trained on OJT Checklists as detailed in QWI-18.1.3. These checklists include required plant system training, required reading, written examination, and proficiency of operating the specific equipment being used (under the supervision of Engineer). Operators cannot run the equipment unsupervised until the checklist is complete and signed. At this time, there are no qualified operators for TRISO coating because there have not been sufficient coating runs to satisfy the OJT requirements. The in-process OJT checklists are kept by the Floor Supervisor in a desk drawer for easy access during training and assessments. When completed, the qualification records will be copied and transmitted to Quality Assurance.

\begin{tabular}{|l|l|l|}
\hline \multicolumn{2}{|l|}{ Objective Evidence } \\
\hline 1. & QWI-18.1.3 & On-the -Job Training \\
\hline 2. & QWI-16.1.2 & UPRR Quality Assurance Records \\
\hline 3. & OJT checklists & $\begin{array}{l}\text { Individual Operator in-process checklists reviewed: } \\
\text { Randy Steele, Tom Markham, Rob Lindsey, Chase Haney, Jason Hall, } \\
\text { Stanley Glover, and Monica Culpepper }\end{array}$ \\
\hline
\end{tabular}

\section{Chemical Inventories for Fabrication and Chemical Characterization}

An inventory sheet was provided that included chemical inventories for the coating operation and consumables such as graphite furnace retort components. The review team assessed the quantity on hand as being sufficient for performing more than the five pre-production and five production coating runs planned. The engineer over TRISO coating operations (Joe Keeley) verbally affirmed that the supplies exceed what is required for the planned runs.

Certificates of Analysis for reactive coating gases and hydrogen were reviewed. The requested purities and the as-received purities were compliant with SPC-1363 "AGR-5/6/7 Fuel Fabrication Feedstock Chemical Purity Specifications," Rev.2 except for acetylene. Most of the acetylene certificates did report purity and impurities analyses in compliance with the specification. Three certificates indicated an incorrect "Requested Purity" for the impurities and one certificate reported impurities as possibly exceeding the SPC-1363 limits. Only one acetylene cylinder is suspect. This was communicated to BWXT during the review. The suspect cylinder is one of several loose spare cylinders and not part of the inventory installed in the primary and reserve cylinder banks for AGR-5/6/7.

The analytical laboratory was toured and a chemist and analyst interviewed. Both have affirmed that the present inventory of chemicals exceed quantities needed for the anticipated number of analyses to be performed. The lead time to order additional chemicals is short enough that additional supplies could be ordered if more analyses became necessary.

The inventory of the gases to be used in applying the TRISO coatings on fuel kernels for the AGR$5 / 6 / 7$ is calculated to be sufficient and purities compliant with SPC-1363, except for the single acetylene cylinder that will not be authorized for use. 


\begin{tabular}{|c|c|c|}
\hline \multicolumn{3}{|c|}{ Objective Evidence } \\
\hline 1. & --- & Inventory spreadsheet (process chemicals and graphite parts) \\
\hline 2. & --- & $\begin{array}{l}\text { Interviews with engineering staff, analysts, and management with verbal } \\
\text { statement that inventory was deemed to be in excess of what will be needed } \\
\text { for pre-production and production coating runs. }\end{array}$ \\
\hline 3. & --- & Field inspection of analytical laboratory \\
\hline 4. & $\begin{array}{l}\text { Job Order No. } \\
000001115136\end{array}$ & AGR Graphite Parts Inspection \\
\hline 5. & $\begin{array}{l}\text { Job Order No. } \\
000001119781\end{array}$ & AGR Graphite Parts Inspection \\
\hline 6. & $\begin{array}{l}\text { Job Order No. } \\
000001133750\end{array}$ & AGR Graphite Heating Element Inspection \\
\hline 7. & $\begin{array}{l}\text { Job Order No. } \\
000001141679\end{array}$ & AGR Graphite Furnace Tube Inspection \\
\hline 8. & $\begin{array}{l}\text { Purchase Order } \\
47000349308 / 30 / 15\end{array}$ & Graphite Chalice, Nozzle, and Extension (SAP Req. 20020161) \\
\hline 9. & $\begin{array}{l}\text { Purchase Order } \\
47000349336 / 8 / 15\end{array}$ & $\begin{array}{l}\text { CENTORR Vacuum Industries Graphite and Other Parts for Work Station } \\
300 \text { (SAP Req. 20020230) }\end{array}$ \\
\hline 10. & $\begin{array}{l}\text { Purchase Order } \\
470003538610 / 2 / 15\end{array}$ & $\begin{array}{l}\text { Acetylene, Atomic Absorption Grade, Minimum Purity 99.6\%, } 323 \mathrm{Cu} \mathrm{Ft} \\
\text { Cylinder (Size } 5 \text { Cylinder) (SAP Req. 20020241) }\end{array}$ \\
\hline 11. & $\begin{array}{l}\text { ACE-8 } \\
\text { ACE-9 } \\
\text { ACE-10 } \\
\text { ACE-11 } \\
\text { ACE-13 } \\
\text { ACE-14 } \\
\text { ACE-15 } \\
\text { ACE-16 }\end{array}$ & Certificates of analysis for acetylene shipped from Airgas and AirProducts. \\
\hline 12. & Release H-010 & Bulk Hydrogen \\
\hline 13. & $\begin{array}{l}\text { Releases } \\
\qquad \text { PROP-02 }\end{array}$ & Propylene \\
\hline
\end{tabular}




\begin{tabular}{|c|c|l|}
\hline \multicolumn{2}{|c|}{ Objective Evidence } \\
\hline & PROP-03 & \\
& PROP-06 & \\
& PROP-07 & \\
\hline 14. & Release MTS-015 & Methyltrichlorosilane \\
\hline
\end{tabular}

\section{Consumables Inventory}

The inventory of consumable graphite parts (chalices, gas distributor nozzles, etc.) was inspected and assessed as being adequate to meet the needs for AGR pre-production and AGR production runs. The engineer verbally confirmed that he expects the inventory to be more than adequate. Parts are inspected for compliance with the tolerances specified in the BWXT fabrication drawings, non-conforming parts are dispositioned such that they will not be used for AGR production runs.

\begin{tabular}{|c|c|c|}
\hline \multicolumn{3}{|c|}{ Objective Evidence } \\
\hline 1. & --- & Inventory spreadsheet (process chemicals and graphite parts) \\
\hline 2. & --- & Interviews with engineering staff \\
\hline 3. & $\begin{array}{l}\text { Job Order No. } \\
000001115136\end{array}$ & AGR Graphite Parts Inspection \\
\hline 4. & $\begin{array}{l}\text { Job Order No. } \\
000001119781\end{array}$ & AGR Graphite Parts Inspection \\
\hline 5. & $\begin{array}{l}\text { Job Order No. } \\
000001141679\end{array}$ & AGR Graphite Furnace Tube Inspection \\
\hline 6. & $\begin{array}{l}\text { Purchase Order } \\
47000349308 / 30 / 15\end{array}$ & Graphite Chalice, Nozzle, and Extension (SAP Req. 20020161) \\
\hline \multirow[t]{2}{*}{7.} & QCDN J52F-0074 & Quality Control Deficiency Notice on the AGR Nozzle dimensions \\
\hline & QCDN J52F-0075 & Quality Control Deficiency Notice on the AGR Chalice dimensions \\
\hline 8. & N-74 J52F-002 & Data Transmittal Form: QCDN No. J52F-0074 and QCDN No. J52F-0075 \\
\hline
\end{tabular}

\section{Material Procurements}

The material procurement process is generally compliant. Level I and Level II items are procured from suppliers listed on the Approved Suppliers List (ASL). Suppliers are audited and the approval level and approved criteria are listed on the ASL. Certificates of Compliance are received as applicable and required inspections are completed and documented.

Contrary to NQA-1-2008/-1a-2009 Section 4, technical requirements were not communicated to the supplier via the purchase requisition/purchase order system. Acetylene was ordered from Air Gas with a

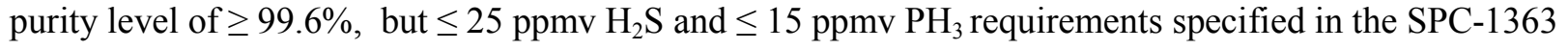


“AGR-5/6/7 Fuel Fabrication Feedstock Chemical Purity Specifications," Rev. 2 were not communicated to the supplier. Three certificates of analysis for acetylene indicated incorrect "Purity Requested" values and one indicated an analytical value for $\mathrm{PH}_{3}$ of $\leq 25 \mathrm{ppmv}$ and therefore suspect. All other gases and consumables were purchased to the required specifications and certificates of analyses showed compliance with the specification.

\begin{tabular}{|c|c|c|}
\hline \multicolumn{3}{|c|}{ Objective Evidence } \\
\hline 1. & QWI 6.1.15 & Technical Requirements for UPRR Purchased Items \\
\hline 2. & Q8-9909 & Supplier Corrective Action Request (in process) \\
\hline 3. & Q8-9930 & Acetylene - Certificate of Batch Analysis- Air Gas 8/14/13 \\
\hline 4. & Q8-9930 & Bulk Hydrogen - Certificate of Batch Analysis- Air Gas 4/15/15 \\
\hline 5. & Q8-9930 & Propylene - Certificate of Batch Analysis- Air Gas 6/10/13 \\
\hline 6. & $\begin{array}{l}\text { Approved Supplier } \\
\text { List (ASL) }\end{array}$ & NOG-L Composite Subcontractor Database (Approved Supplier) \\
\hline 7. & Audit & $\begin{array}{l}\text { Supplier audit of DuBose in September } 2015 \text { to qualify to NQA-1-2008/-1a- } \\
\text { 2009, } 10 \text { CFR } 50 \text { QA Criteria for Nuclear Power Plants and Fuel Processing } \\
\text { Plants, NCA-3800 ASME Boiler and Vessel Code, and } 10 \text { CFR } 21 \\
\text { Reporting of Defects and Noncompliances }\end{array}$ \\
\hline 8. & PR 20020161 & PO 470034930 including associated drawings \\
\hline 9. & PR20020230 & Level 3 - not safety significant \\
\hline 10. & PR 20019917 & Level 2 - Hydril cylinders $\geq 99.95 \%$ \\
\hline 11. & PR 20019917 & Level 2 - Acetylene $-\geq 99.6 \% \leq 25$ ppmv $\mathrm{H}_{2} \mathrm{~S} \leq 15$ ppmv $\mathrm{PH}_{3}$ \\
\hline 12 & PO 4700035386-0 & Air Gas - 12/9/2015 Acetylene - $\geq 99.6 \%$ \\
\hline 13 & $\begin{array}{l}\text { Job Order No. } \\
000001115136\end{array}$ & AGR Graphite Parts Inspection - Quality Control Data Sheet \\
\hline 14 & $\begin{array}{l}\text { Job Order No. } \\
000001133750\end{array}$ & AGR Graphite Heating Element Inspection- Quality Control Data Sheet \\
\hline 15 & $\begin{array}{l}\text { Job Order No. } \\
000001141679\end{array}$ & AGR Graphite Furnace Tube Inspection- Quality Control Data Sheet \\
\hline
\end{tabular}

\section{Operability of Essential TRISO Coating Furnace and Ancillary Equipment}

An examination by BWXT of the coating furnace following an interrupted coating "test" run, to verify equipment functionality, revealed an unacceptable degradation of insulation and ceramic insulators surrounding the electrical lead-ins for the heating elements. The furnace manufacturer, CENTORR, had made recent changes in these materials. BWXT is working with CENTORR to resolve the issue and to obtain insulation and insulators known to have worked well in the past. 
The coating test run was interrupted because the desired hydrogen flow rate could not be established. A post run inspection identified that a flow control valve had failed. BWXT is in the process of checking calibration on a spare flow control valve.

The coating furnace, work station WS-300, is not presently ready for operation. The scrubber system and off-gas filtration systems performed as designed.

\section{Objective Evidence}

\begin{tabular}{|l|l|l|}
\hline 1. & -- & Interviews with engineering staff and management \\
\hline
\end{tabular}

\section{Corrective Actions System Effectiveness to Capture "Lessons Learned"}

BWXT has a defined corrective action process that is compliant with NQA-1-2008/-1a-2009 requirements that have three paths of investigation depending on the level of severity. Lessons learned reports are sent to all employees in a Quality Advisory. The corrective actions listed below were reviewed and found to be adequately documented and compliant.

\begin{tabular}{|c|c|c|}
\hline \multicolumn{3}{|c|}{ Objective Evidence } \\
\hline 1. & QWI-14.1.1 & Preventative/Corrective Action System \\
\hline 2. & $\begin{array}{l}\text { QWI-14.1.1 } \\
\text { Attachment } 1\end{array}$ & Preventative/Corrective Action System Severity Level \\
\hline 3. & QWI-14.1.3 & Lessons Learned Report \\
\hline 4. & Form Q8-9909 & Supplier Corrective Action Report \\
\hline 5. & CA 201501878 & Sample Calculation incorrect - wrong valve used \\
\hline 6. & CA 201501400 & AGR coating run acetylene flow incorrect due to Windows 7 update \\
\hline 7. & CA 20150188 & Chemical near miss- chemical tipped over \\
\hline 8. & Quality Advisory & Incompatible Valve Material in Systems Containing Acid \\
\hline
\end{tabular}

\section{Product acceptance}

BWXT has processes for the receipt inspection of materials to drawings and has the analytical methods to ensure that TRISO coated particles are compliant with fuel specifications, with two exceptions. High resolution X-ray imaging technology for IPyC defect fraction analysis is not available at BWXT and the ellipsometer used for pyrocarbon anisotropy measurements is out-of-service for upgrades. Arrangements have been made by INL with Oak Ridge National Laboratory (ORNL) to perform analyses for IPyC defect fraction and temporarily for the pyrocarbon anisotropy until the BWXT ellipsometer is back in service.

BWXT analytical personnel are running analyses on archived TRISO coated particles to refamiliarize themselves with the methods and the equipment.

The review team is confident in the ability of BWXT, with support from ORNL, to ensure that the AGR-5/6/7 TRISO coated particles are fabricated with equipment meeting dimension tolerances, that gases used will meet purity specifications, and that only TRISO coated particles meeting fuel specifications will be accepted for AGR-5/6/7. 


\begin{tabular}{|c|c|c|}
\hline \multicolumn{3}{|c|}{ Objective Evidence } \\
\hline 1. & --- & J52O-16-93160 kernel density and wt/count analyses \\
\hline 2. & --- & J52O-16-93161 buffer density, wt/count, and envelope density \\
\hline 3. & --- & $\mathrm{J} 52 \mathrm{O}-16-93161$ isotopic analyses \\
\hline 4. & $\begin{array}{l}\text { Job Order No. } \\
000001115136\end{array}$ & AGR Graphite Parts Inspection - Quality Control Data Sheet \\
\hline 5 . & $\begin{array}{l}\text { Job Order No. } \\
000001133750\end{array}$ & AGR Graphite Heating Element Inspection- Quality Control Data Sheet \\
\hline 6. & $\begin{array}{l}\text { Job Order No. } \\
000001141679\end{array}$ & AGR Graphite Furnace Tube Inspection- Quality Control Data Sheet \\
\hline 7. & --- & Interviews with the analytical chemist and technician \\
\hline
\end{tabular}

\section{Handling and Storage}

An electronic system MAP issues maintenance plans to the floor on a weekly basis. QCDNs are issued for nonconforming items and those items are appropriately marked and/or removed from service.

A review of Quality Control Deficiency Notices (QCDNs) showed two instances of the documents signed as completed prior to the disposition codes being recorded. QCDN J52F-0075 AGR Chalice diameter size and J52F-0074 - AGR Nozzle were signed without disposition codes assigned. A suggested disposition pending customer (BEA) approval was written on the forms but Form Q11-127 was signed prior to the customer's approval of this disposition on 10/31/13 (recorded on Form N-74). These instances had no negative impact due to the customer's approved disposition of "use as is". However, approval prior to final disposition does not preclude use of nonconforming items if the final disposition were to "reject" or "rework".

\begin{tabular}{|c|l|l|}
\hline \multicolumn{3}{|l|}{ Objective Evidence } \\
\hline 1. & QCDN J52F-0074 & Quality Control Deficiency Notice on the AGR Nozzle dimensions \\
\hline 2. & QCDN J52F-0075 & Quality Control Deficiency Notice on the AGR Chalice dimensions \\
\hline 3. & N-74 J52F-002 & Data Transmittal Form: QCDN No. J52F-0074 and QCDN No. J52F-0075 \\
\hline 4. & $\begin{array}{l}\text { OP-1016020 Rev. } \\
10\end{array}$ & $\begin{array}{l}\text { Operating Procedure for: AGR Coating Furnace Scrubber Operation and } \\
\text { Maintenance (U) }\end{array}$ \\
\hline 5. & OP-1015211 Rev. 5 & Operating Procedure for: Sieving for AGR (U) \\
\hline 6. & --- & Inventory spreadsheet (process chemicals and graphite parts) \\
\hline 7. & --- & Interviews with engineering staff, analysts, and management \\
\hline 8. & --- & Field inspection of analytical laboratory \\
\hline
\end{tabular}




\section{Personnel Access and Familiarity with Latest AGR Work Scope and Requirements Documents}

The AGR work scope and specification documents are controlled at the INL and formally transmitted to BWXT management through procurement and contract management. These documents are reviewed and approved by BWXT. The Lead Engineer distributes the applicable requirements to the production floor via OJT checklists and briefings.

\begin{tabular}{|c|l|l|}
\hline \multicolumn{2}{|l|}{ Objective Evidence } \\
\hline 1. & SMT-5050021-001 & SOLUMINA Move Ticket: AGR Graphite Inspection \\
\hline 2. & $\begin{array}{l}\text { Process OJT } \\
\text { Checklists }\end{array}$ & $\begin{array}{l}\text { Randy Steele, Tom Markham, Rob Lindsey, Chase Haney, Jason Hall, } \\
\text { Stanley Glover, and Monica Culpepper }\end{array}$ \\
\hline 3. & --- & Interviews with engineering staff and management \\
\hline
\end{tabular}

\section{Considerations from Previous Reviews and Incidents}

Shortcomings from previous readiness reviews were revisited to ensure that corrective actions were effective. In a previous review, multiple calibrated check weight sets were found in the gloveboxes used for handling fuel kernels and TRISO coated fuel particles without the performer noting which check weight set had been used. BWXT resolved this by removing redundant check weight sets. This corrective action is effective for both kernel and TRISO particle fabrication.

A previous review found that training records were not signed by an authorized individual (manager or lead engineer) and one case was found that a qualification exam had not been graded. The review team inspected training records and found that all required signatures were in place. Many of the documents are still working documents and not yet finalized as records, but the review team finds the BWXT process to be effective.

A previous review for TRISO particle coating identified a lack of receipt inspection for graphite parts to ensure that the parts were compliant with the dimensional tolerances specified in fabrication drawings. This review found evidence that graphite parts are receipt inspected to verify conformance to drawing dimensional tolerances and that non-conforming parts approved only for non-production coating trials. The review team is confident that corrective actions taken previously by BWXT have been effective.

\begin{tabular}{|l|l|l|}
\hline \multicolumn{2}{|l|}{ Objective Evidence } & \\
\hline 1. & OP-0390001 & Operating Procedure for: Product Identification Control (U) \\
\hline 2. & --- & Interviews with, SFF Frontline Manager, engineering staff, and management \\
\hline 3. & QCDN J52F-0074 & Quality Control Deficiency Notice on the AGR Nozzle dimensions \\
\hline 4. & QCDN J52F-0075 & Quality Control Deficiency Notice on the AGR Chalice dimensions \\
\hline 5. & N-74 J52F-002 & Data Transmittal Form: QCDN No. J52F-0074 and QCDN No. J52F-0075 \\
\hline 6. & $\begin{array}{l}\text { Job Order No. } \\
\text { AGR Graphite Parts Inspection - Quality Control Data Sheet }\end{array}$ \\
\hline
\end{tabular}




\begin{tabular}{|l|l|l|}
\hline \multicolumn{2}{|l|}{ Objective Evidence } \\
\hline 7. & $\begin{array}{l}\text { Job Order No. } \\
000001133750\end{array}$ & AGR Graphite Heating Element Inspection- Quality Control Data Sheet \\
\hline 8. & $\begin{array}{l}\text { Job Order No. } \\
000001141679\end{array}$ & AGR Graphite Furnace Tube Inspection- Quality Control Data Sheet \\
\hline 9. & QWI-18.1.3 & On-the -Job Training \\
\hline 10. & QWI-16.1.2 & UPRR Quality Assurance Records \\
\hline 11. & OJT checklists & $\begin{array}{l}\text { Individual Operator in-process checklists reviewed: } \\
\text { Randy Steele, Tom Markham, Rob Lindsey, Chase Haney, Jason Hall, } \\
\text { Stanley Glover, and Monica Culpepper }\end{array}$ \\
\hline
\end{tabular}

\section{CONCLUSIONS}

The readiness review team was cordially received and provided with examples of objective evidence, which had been compiled in advance of the review by BWXT. Additional information was provided when requested. The review was productive and professionally facilitated by BWXT. Arrangements were made in a timely manner by BWXT for the team to meet with key individuals and to conduct spot checks in the field.

The readiness review team finds that BWXT will be ready to fabricate TRISO coated fuel particles once the coating furnace operability has been successfully demonstrated and the two findings have been addressed. Functionality of the coating furnace will be adequately demonstrated when the test run, check run, and at least one pre-production run have been successfully completed without major equipment failures. Both findings are related to awareness of processes to preclude suspect and off-spec materials and chemicals from being used in the fabrication of the AGR-5/6/7 TRISO coated fuel; one being communication of all purity specifications to suppliers during procurement of chemicals and the other is ensuring appropriate disposition codes are given when Quality Control Deficiency Notices (QCDN) are signed. BWXT is expected provide information on corrective actions taken to address these findings. 
APPENDIX A

CONTENTS OF THE BWXT OBJECTIVE EVIDENCE BINDER 


\section{TABLE OF CONTENTS}

OP-1015720 COATING IN THE CENTORR FURNACE FOR ADVANCED GAS REACTOR PROGRAM

OP-1016020 AGR COATING FURANCE SCRUBBER OPERATION AND MAINTENANCE

OP-1015211 SIEVING FOR AGR

OP-1015306 TABLER OPERATION FOR ADVANCED GAS REACTOR PROGRAM

OP-1015213 SPLIT BLEND OPERATION FOR AGR

PP0-0930001 AGR COATING

OP-0390001 PRODUCT IDENTIFICATION CONTROL

CORRECTIVE ACTION

DRAWINGS:

CRF-306

SFF-156

UPRR-10002

UPRR-10031

UPRR-10032

UPRR-10033

UPRR-10035

QW1-11.1 CONTROL OF MEASURING AND TEST EQUIPMENT (CALIBRATIONS)

QW1-4.1.6 UPRR PROCESS DESIGN CRITERIA

QW1-5.1.1 CONTROL OF PLAN LIST FOR DOCUMENTS

QW1-5.1.3 PREPARATION OF ROUTING DOCUMENT FOR NON-NR CONTRACTS

QW1-5.1.4 OPWERATING PROCEDURES

QW1-5.1.11 DRAWING CONTROL SYSTEM

QWI-5.1.12 CHANGE MANAGEMENT

QW1-6.1.15 TECHNICAL REQUIREMENT FOR UPRR PURCHASED ITEMS

QWl-14.1.1 PREVENTIVE/CORRECTIVE ACTION SYSTEM

QWl-14.1.1 ATTACHMENT 1 PREVENTIVE/CORRECTIVE ACTION SYSTEM SEVERTY LEVELS PURCHASE ORDERS/REQUISITIONS

INVENTORY

CR-1044974

CHEMISTRY ANALYSIS

SAP MAINTENANCE PLAN

OJT CHECK SHEET

CALIBRATED EQUIPMENT

JOB ORDER \# 000001115136

JOB ORDER \# 000001119781

JOB ORDER \# 000001133750

JOB ORDER \# 000001141679

QUALITY CONTROL DEFICIENCY NOTICE

QCDN

MOVE TICKET 


\section{APPENDIX B \\ READINESS REVIEW ATTENDANCE SHEET}


AGR-5/6/7 TRIO PARTICLE FABRICATION READINESS REVIEW ATTENDANCE SHEET

Vendor BW xT

Dates $2 / 9 / 2016-z / 10 / 2016$ Location Lymchbuy, IA Technical Lead Doyelas Marshall Quality Engineer Michelle Tharp.

Attendees:

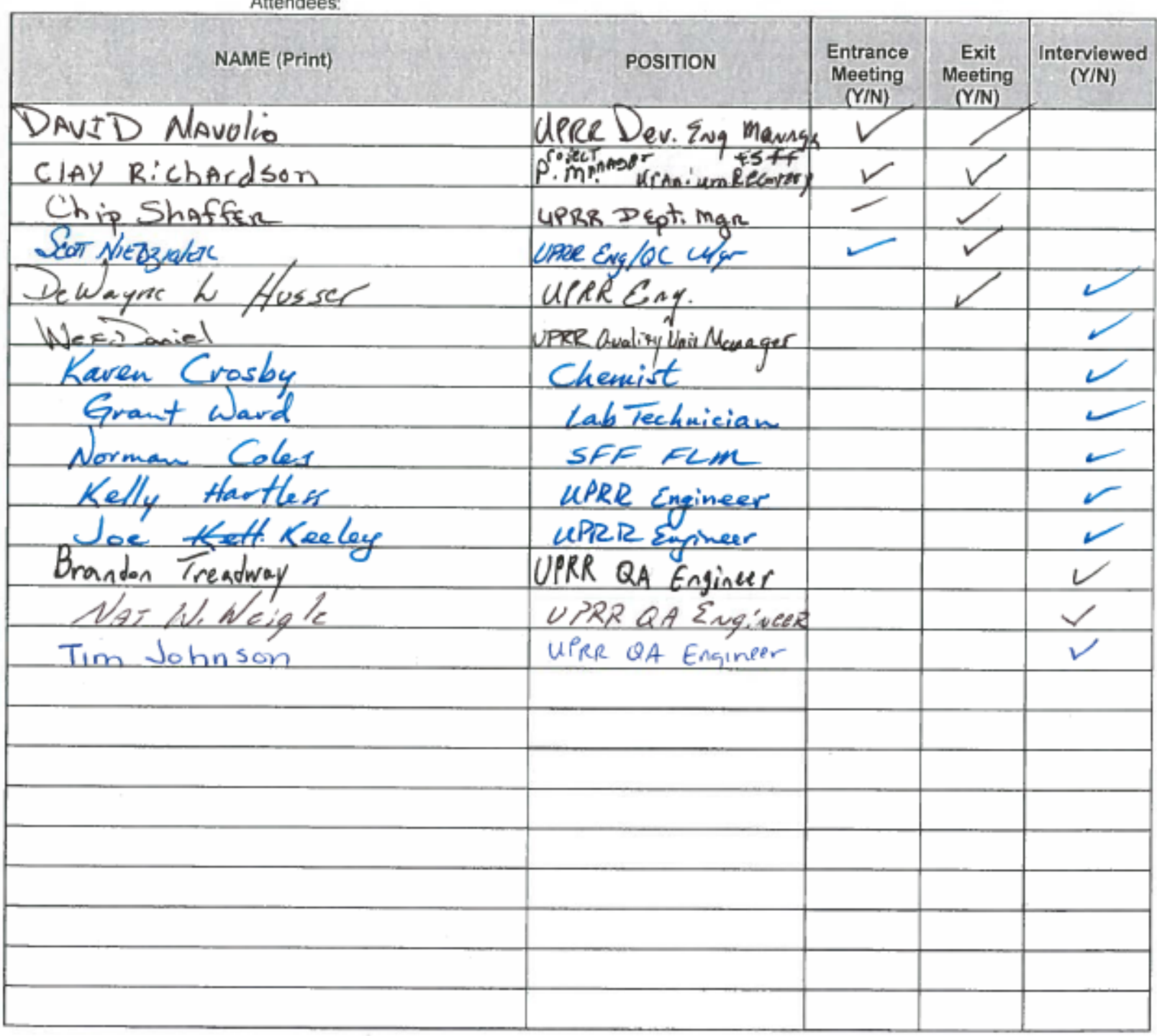

Comments:

B-2 


\section{APPENDIX C \\ READINESS REVIEW PLAN}




\section{READINESS REVIEW CRITERIA \\ AGR-5/6/7 TRISO PARTICLE FABRICATION}

The following focus areas are subject to scrutiny by the readiness review team as each applies to LEU TRISO particle fabrication activities (e.g., coating, upgrading, etc.) described in SOW-11518 (Rev.7) "AGR-5/6/7 Fuel Fabrication." INL will focus the areas below as they apply to TRISO coated particle fabrication, but INL will respond to the information and objective evidence obtained and follow leads as necessary to assess readiness.

A visit to the processing area is requested to allow reviewers to see the equipment and make limited inspections of calibration stickers and equipment condition.
References to NQA-1 mean ASME-NQA-1-2008/1a-2009. The outline below may not quote the entire text of each referenced paragraph within a NQA-1 requirement. Nevertheless, objective evidence may be requested by the review team to demonstrate compliance with all requirements within the referenced paragraph.

Documents and objective evidence presented by BWXT to INL should be associated with activities related to the AGR fuel fabrication. It is understood that BWXT has the prerogative to either refuse presentation of evidence that may contain classified or sensitive information or to present redacted documents as evidence of compliance.

\begin{tabular}{|c|c|}
\hline Focus Area & Suggested Objective Evidence \\
\hline 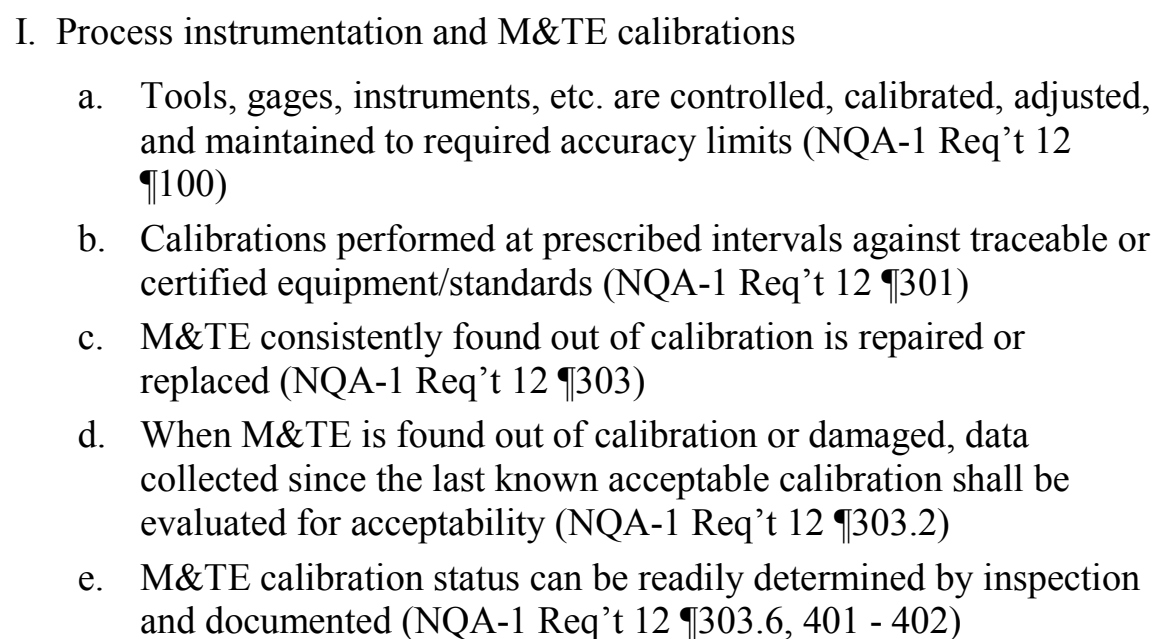 & $\begin{array}{l}\text { - List of calibrated process instruments with calibration intervals } \\
\text { - List of tools, gages, weights, etc. that require calibration and } \\
\text { calibration intervals } \\
\text { - Evidence that the calibrations are traceable to certified } \\
\text { equipment or standards } \\
\text { - Evidence that the calibrations are current } \\
\text { - Acceptability evaluations for M\&TE out of calibration }\end{array}$ \\
\hline
\end{tabular}




\begin{tabular}{|c|c|}
\hline Focus Area & Suggested Objective Evidence \\
\hline 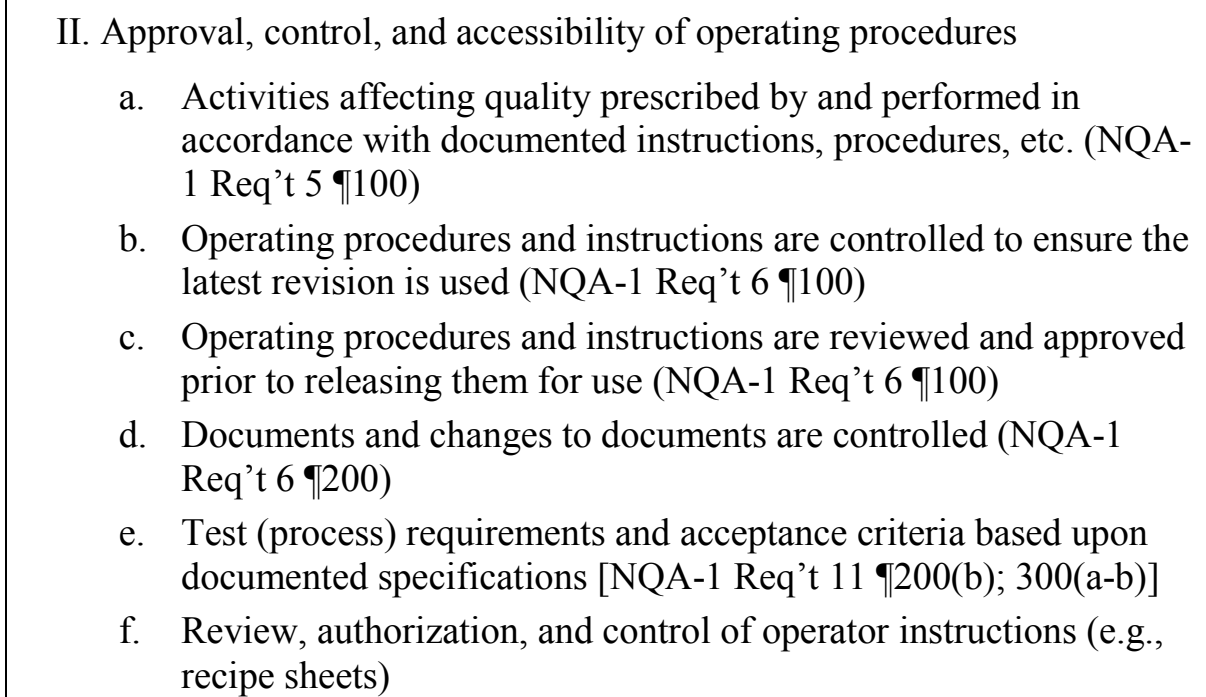 & $\begin{array}{l}\text { - Binder containing copies of current operating procedures } \\
\text { applicable to activities associated with applying TRISO } \\
\text { coatings and analytical methods for characterization } \\
\text { - Evidence that only the current procedures and instructions are } \\
\text { available to those performing the work } \\
\text { - Evidence that changes to controlled instructions, methods, or } \\
\text { procedures are authorized by management } \\
\text { - Evidence of operating instructions or recipe sheets being } \\
\text { authorized } \\
\text { - Records showing how performers know that they have the } \\
\text { latest recipe sheet/instruction version }\end{array}$ \\
\hline $\begin{array}{l}\text { Process record control and accessibility } \\
\text { a. Records are validated or authenticated by authorized personnel } \\
\text { [NQA-1 Req't } 17 \llbracket 300(\mathrm{a})]\end{array}$ & $\begin{array}{l}\text { - } \\
\text { - Examples of validated/authenticated AGR records - inspection } \\
\text { reports, training records, etc. }\end{array}$ \\
\hline $\begin{array}{l}\text { IV. Configuration design and control } \\
\text { a. Procedures established to implement configuration management } \\
\text { and responsibilities/authorities are identified (NQA-1 Req't } 3 \\
\text { \601) } \\
\text { b. Configuration changes affecting quality are (NQA-1 Req't } 3 \\
\text { \601.1 - 601.9): } \\
\text { i. Recognized before implementation } \\
\text { ii. Analyzed against design bases and requirements } \\
\text { iii. Approved by responsible persons } \\
\text { iv. Documented (incl. basis) } \\
\text { c. Controls are established to ensure that only correct and accepted } \\
\text { items (e.g., materials of construction) are used or installed (NQA- } \\
\text { 1 Req't } 8 \text {-100 - 303) }\end{array}$ & $\begin{array}{l}\text { - Documentation associated with recent maintenance or } \\
\text { configuration changes demonstrating the focus points to the } \\
\text { right. }\end{array}$ \\
\hline
\end{tabular}




\begin{tabular}{|c|c|c|}
\hline & Focus Area & Suggested Objective Evidence \\
\hline V. & 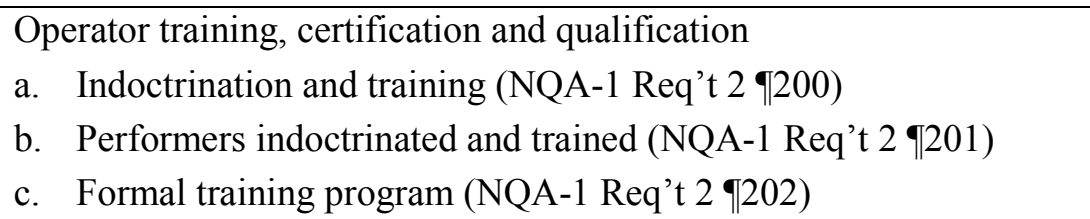 & $\begin{array}{l}\text { - Training plans, training rosters, etc. } \\
\text { Management concurrence that training was completed and } \\
\text { effective }\end{array}$ \\
\hline VI. & $\begin{array}{l}\text { Chemical inventories for fabrication and chemical characterization } \\
\text { a. Chemical inventories are sufficient for expected needs or a plan is } \\
\text { in place to acquire chemicals before the inventory is depleted. } \\
\text { b. Chemical shelf-lives will not be exceeded during the period of } \\
\text { TRISO particle fabrication (NQA-1 Req't } 89302 \text { ) } \\
\text { c. Chemicals comply with SPC-1363, “AGR-5/6/7 Fuel Fabrication } \\
\text { Feedstock Chemical Purity Specifications," Rev. } 2\end{array}$ & $\begin{array}{l}\text { - Chemical certificates of conformance and expiration dates (as } \\
\text { applicable) } \\
\text { - Spreadsheet of process and analytical chemicals with: } \\
\circ \text { Quantities on hand } \\
\circ \text { Quantities needed for remaining pre-production runs and at } \\
\text { least six }(5+1) \text { production runs } \\
\circ \text { Plans to acquire any deficient inventories }\end{array}$ \\
\hline VII. & $\begin{array}{l}\text { Consumables inventory (e.g., graphite furnace parts) is adequate for } \\
\text { expected needs and spares }\end{array}$ & $\begin{array}{l}\text { - Quantities of graphite parts (chalice, nozzles, etc.) needed to } \\
\text { complete pre-production and production runs } \\
\text { - Quantities in inventory } \\
\text { - } \quad \text { Plans to acquire any needed parts }\end{array}$ \\
\hline VIII. & 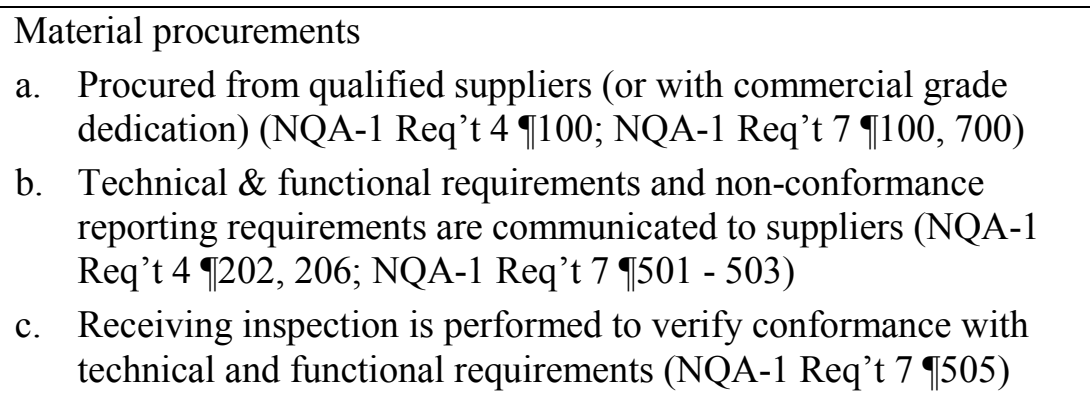 & $\begin{array}{l}\text { - Sample procurement documents } \\
\text { - } \quad \text { Eualified supplier list (as applicable to TRISO fabrication) } \\
\text { communicated to the vendor } \\
\text { - Evidence of receipt inspections being completed and } \\
\text { conformance of items to the technical and functional } \\
\text { requirements (e.g., dimensions on nozzles and chalices, etc.) }\end{array}$ \\
\hline IX. & $\begin{array}{l}\text { Operability of essential TRISO coating furnace and ancillary } \\
\text { equipment }\end{array}$ & $\begin{array}{l}\text { Equipment walk-down to inspect equipment and } \\
\text { instrumentation for cleanliness, material compatibility, out-of- } \\
\text { service tags, current calibrations, general condition, etc. }\end{array}$ \\
\hline
\end{tabular}




\begin{tabular}{|c|c|c|}
\hline & Focus Area & Suggested Objective Evidence \\
\hline X. & 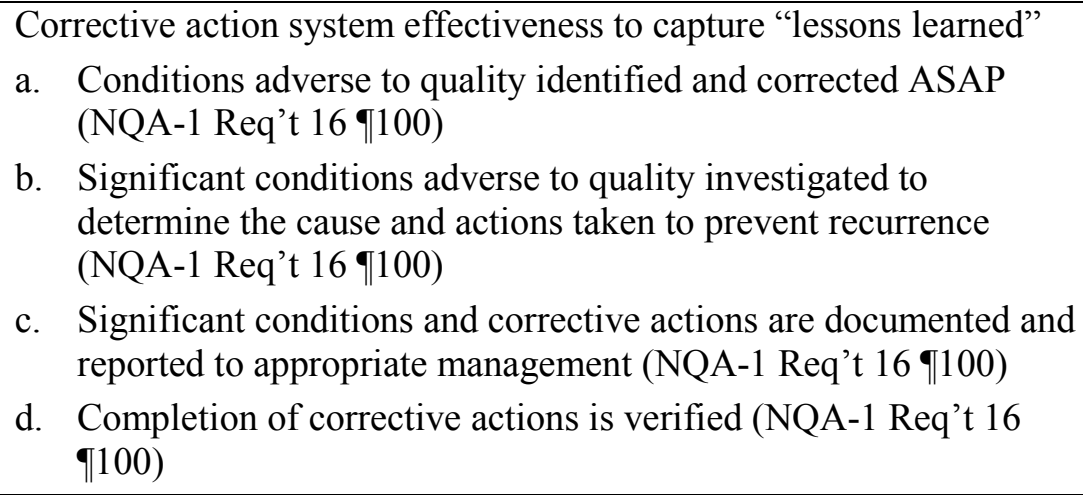 & $\begin{array}{l}\text { Documentation of a recent incident where conditions adverse } \\
\text { to quality were identified, investigated, corrected, reported, } \\
\text { and documented } \\
\text { Evidence that other processes were reviewed for similar } \\
\text { conditions } \\
\text { Evidence demonstrating that the corrective actions are durable } \\
\text { (lessons learned are not forgotten) }\end{array}$ \\
\hline XI. & 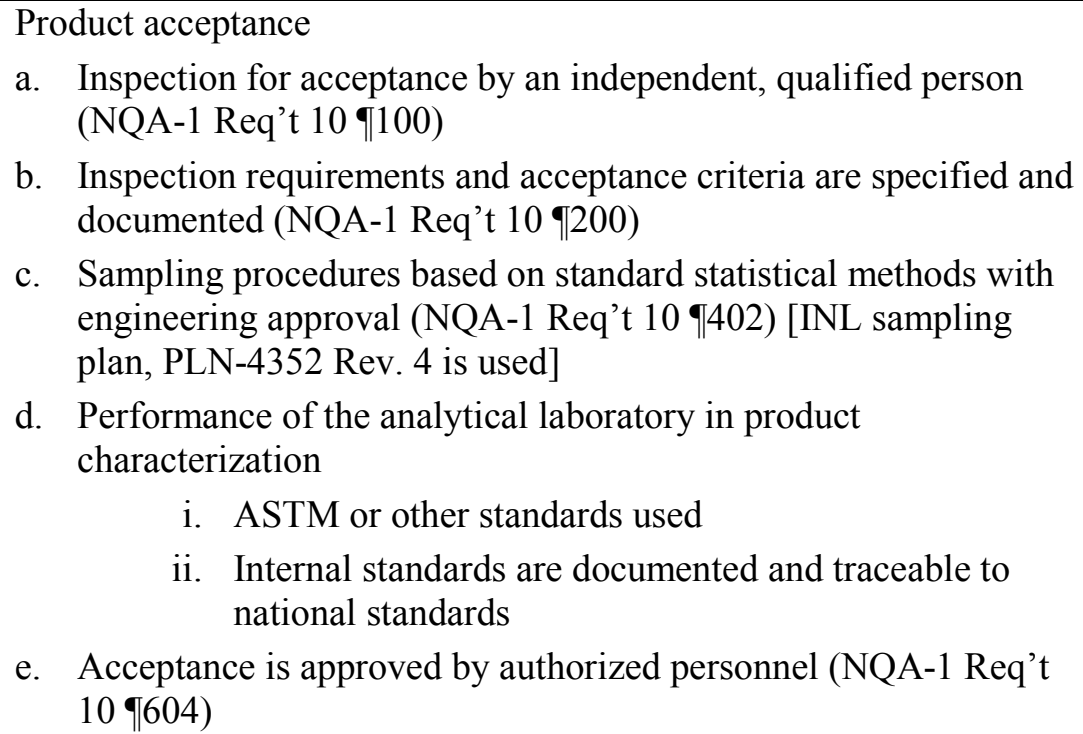 & $\begin{array}{l}\text { Documentation showing acceptance or rejection of product to } \\
\text { - } \\
\text { Documented criteria/specifications } \\
\text { representation samples in quantities sufficient to satisfy the } \\
\text { sampling plan } \\
\text { - Walk-down of the analytical laboratory to verify that } \\
\text { chemicals are current, that the inventory is sufficient to support } \\
\text { characterization, instruments are calibrated, and that standards } \\
\text { are traceable to national standards } \\
\text { - Evidence that analytical results are reviewed for quality and } \\
\text { approved prior to official release }\end{array}$ \\
\hline
\end{tabular}




\begin{tabular}{|c|c|c|}
\hline & Focus Area & Suggested Objective Evidence \\
\hline KII. & 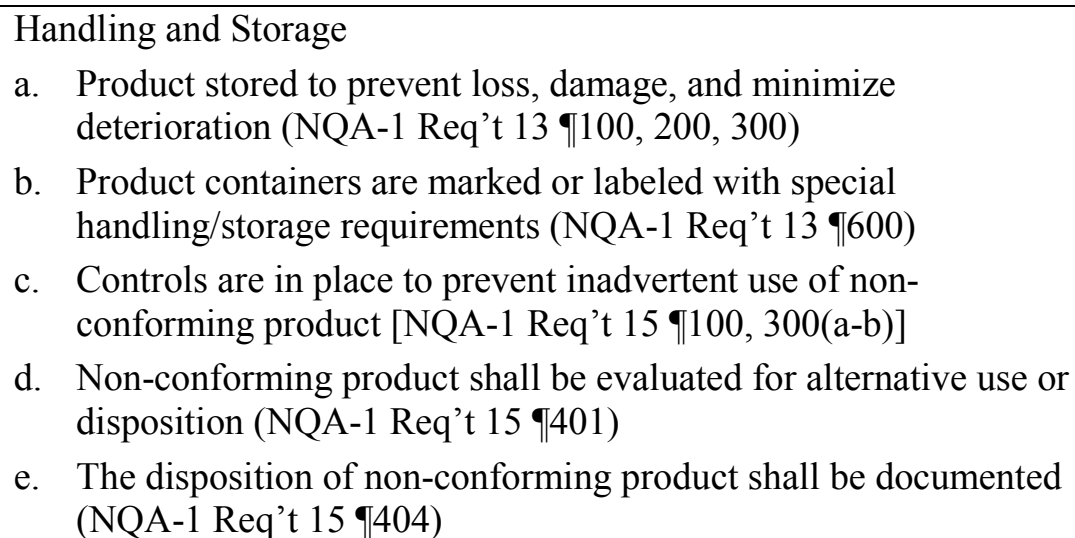 & $\begin{array}{l}\text { Procedures and documents showing how product is segregated } \\
\text { from non-conforming material and controlled to prevent loss } \\
\text { of identity }\end{array}$ \\
\hline XIII. & $\begin{array}{l}\text { Personnel have access to and are familiar with the latest AGR work } \\
\text { scope and requirements documents } \\
\text { a. SOW-11518, "AGR-5/6/7 Fuel Fabrication," Rev. } 6 \\
\text { b. SPC-1352, "AGR-5/6/7 Fuel Specification," Rev. } 5 \\
\text { c. SPC-1363, "AGR-5/6/7 Fuel Fabrication Feedstock Chemical } \\
\text { Purity Specifications," Rev. } 2 \\
\text { d. PLN-4352, "Statistical Sampling Plan for AGR-5/6/7 Fuel } \\
\text { Materials," Rev. } 4\end{array}$ & $\begin{array}{l}\text { - Show how superceded AGR documents are controlled } \\
\text { - Show how current AGR documents are controlled }\end{array}$ \\
\hline
\end{tabular}




\begin{tabular}{|c|c|}
\hline Focus Area & Suggested Objective Evidence \\
\hline $\begin{array}{l}\text { KIV. Considerations from previous reviews and incidents } \\
\text { a. Check weight ID's are recorded when used to verify balance } \\
\text { functionality } \\
\text { b. Training records are signed by management } \\
\text { c. Internal audits reflect assessments of process effectiveness (if an } \\
\text { audit has been performed for unclassified systems associated with } \\
\text { AGR fuel fabrication) } \\
\text { d. Computerized process control functions have been verified } \\
\text { following programming changes or updates to operating systems } \\
\text { e. Coating furnace graphite components are inspected upon receipt } \\
\text { to verify that parts comply with dimensional tolerance limits } \\
\text { f. Materials of construction are compatible with service conditions }\end{array}$ & \\
\hline
\end{tabular}

\section{Prepared by}

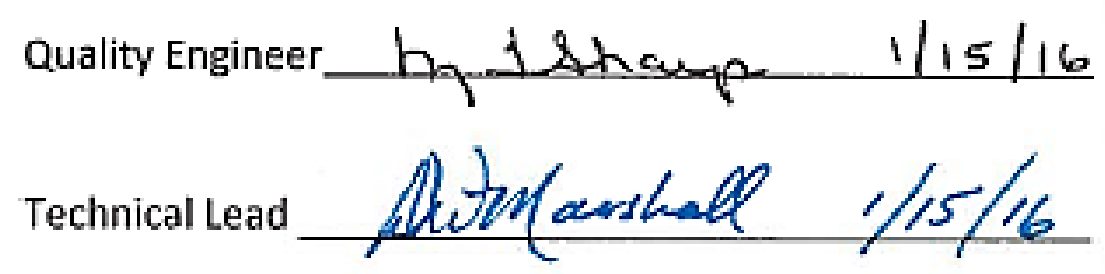

